This is the author's final, peer-reviewed manuscript as accepted for publication. The publisher-formatted version may be available through the publisher's web site or your institution's library.

\title{
Micro-X-Ray Fluorescence, Micro-X-Ray Absorption Spectroscopy, and Micro-X-Ray Diffraction Investigation of Lead Speciation after the Addition of Different Phosphorus Amendments to a Smelter-Contaminated Soil
}

Lucas R. Baker, Gary M. Pierzynski, Ganga M. Hettiarachchi, Kirk G. Scheckel and Matthew Newville

How to cite this manuscript

If you make reference to this version of the manuscript, use the following information:

Newville, M., Scheckel, K. G., Hettiarachchi, G. M., Pierzynski, G. M., \& Baker, L. R. (2014). Micro-X-Ray Fluorescence, Micro-X-Ray Absorption Spectroscopy, and MicroX-Ray Diffraction Investigation of Lead Speciation after the Addition of Different Phosphorus Amendments to a Smelter-Contaminated Soil.

\section{Published Version Information}

Citation: Newville, M., Scheckel, K. G., Hettiarachchi, G. M., Pierzynski, G. M., \& Baker, L. R. (2014). Micro-X-Ray Fluorescence, Micro-X-Ray Absorption Spectroscopy, and Micro-X-Ray Diffraction Investigation of Lead Speciation after the Addition of Different Phosphorus Amendments to a Smelter-Contaminated Soil. Journal of environmental quality, 43(2), 488-497.

Digital Object Identifier (DOI): 10.2134/jeq2013.07.0281

Publisher's Link:

https://www.agronomy.org/publications/jeq/abstracts/43/2/488?search-result=1

This item was retrieved from the K-State Research Exchange (K-REx), the institutional repository of Kansas State University. K-REx is available at http://krex.ksu.edu 


\section{$\mu \mathrm{XRF}, \mu \mathrm{XAS}$ and $\mu \mathrm{XRD}$ Investigation of Pb Speciation after the Addition of Different P Amendments to a Smelter-Contaminated Soil}

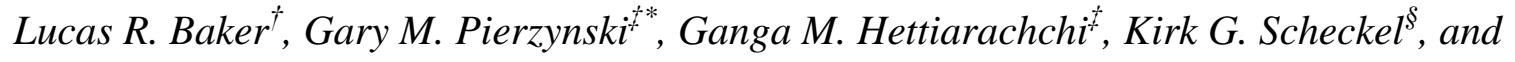
Matthew Newville

${ }^{\dagger}$ Brookside Laboratories, Inc. 308 S. Main Street, New Knoxville, OH, 45871;

${ }^{\ddagger}$ Department of Agronomy, Throckmorton Plant Sciences Center, Kansas State

University, Manhattan, Kansas 66506-5501; ${ }^{\S}$ United States Environmental Protection Agency, National Risk Management Research Laboratory, 5995 Center Hill Ave., Cincinnati, OH 45224; ${ }^{\dagger \dagger}$ Consortium for Advanced Radiation Sources, The University of Chicago, 5640 S Ellis Ave., Chicago, IL 60637.

Corresponding author phone: (785)532-7200; fax: (785)532-6094; email: gmp@ksu.edu Contribution no. 14-011-J from the Kansas Agricultural Experiment Station. 


\begin{abstract}
The stabilization of $\mathrm{Pb}$ upon additions of $\mathrm{P}$ to contaminated soils and mine spoil materials has been well documented. It is clear from the literature that different $\mathrm{P}$ sources result in different efficacies of $\mathrm{Pb}$ stabilization in the same contaminated material. We hypothesized that the differences in efficacy of $\mathrm{Pb}$ stabilization in contaminated soils upon fluid or granular $\mathrm{P}$ amendment addition is due to different $\mathrm{P}$ reaction processes in and around fertilizer granules and fluid droplets. We used a combination of several synchrotron-based techniques, namely, spatially resolved micro-X-ray fluorescence $(\mu-$ $\mathrm{XRF}$ ), micro-X-ray absorption near edge structure spectroscopy ( $\mu$-XANES), and micro$\mathrm{x}$-ray diffraction $(\mu-\mathrm{XRD})$ to speciate $\mathrm{Pb}$ at two incubation times in a smelter contaminated soil upon addition of several fluid and granular P amendments. The results indicated that the $\mathrm{Pb}$ phosphate mineral plumbogummite was an intermediate phase of pyromorphite formation. Additionally, all fluid and granular $\mathrm{P}$ sources were able to induce $\mathrm{Pb}$ phosphate formation, but fluid phosphoric acid (PA) was the most effective with time and distance from the treatment. Granular phosphate rock (PR) and triple super phosphate (TSP) amendments reacted to generate $\mathrm{Pb}$ phosphate minerals, with TSP being more effective at greater distances from the point of application. As a result, PA and TSP were the most effective $\mathrm{P}$ amendments at inducing $\mathrm{Pb}$ phosphate formation, but caution needs to be exercised when adding large additions of soluble $\mathrm{P}$ to the environment.
\end{abstract}

\title{
Introduction
}

Lead $(\mathrm{Pb})$ is a natural constituent of all soils (Adriano, 2001). Soil $\mathrm{Pb}$ concentrations have increased in past years through such processes as mining, sewage sludge application, fossil fuel combustion, and many chemical and other manufacturing 
industries (Adriano, 2001; Basta et al., 2005). A wide variety of health effects of $\mathrm{Pb}$ exposure in children and adults have been recognized (ATSDR, 2005), and according to recent reports, no safe blood $\mathrm{Pb}$ threshold for children has been identified to date (Brown and Margolis, 2012). Lead contaminated soil is a primary source of $\mathrm{Pb}$ exposure to young children. It is well known that different soils with same total $\mathrm{Pb}$ concentrations could have very different bioavailable $\mathrm{Pb}$ concentrations (Scheckel et al, 2009). The bioavailability of $\mathrm{Pb}$ in soils and mine wastes primarily depends on its chemical speciation (Scheckel and Ryan, 2004). In contaminated soils and mine wastes, large fractions of $\mathrm{Pb}$ can exist in potentially bioavailable fractions. Therefore, considerable effort has been focused on developing cost-effective remediation technologies to reduce metal bioavailability and mobility in natural environments (Ryan et al., 2004).

Previously, remediation efforts have principally consisted of removal of the contaminated material with subsequent back-filling with clean soil. However, this process is costly, time consuming, and requires a source of clean soil. Current research involves the potential to change the bioavailability of $\mathrm{Pb}$ in situ by altering its chemical speciation (Mench et al., 1994, Porter et al., 2004). Much of this research has been focused on the addition of $\mathrm{P}$ amendments to $\mathrm{Pb}$ contaminated soils to form $\mathrm{Pb}$ phosphates, particularly pyromorphite, which is one of the most stable $\mathrm{Pb}$ minerals under a wide range of environmental conditions (Nriagu, 1974). As a result, P amendments could be used to reduce the bioavailability/bioaccessibility of $\mathrm{Pb}$ in contaminated soils and mine wastes.

Immobilizing $\mathrm{Pb}$ as pyromorphite in soils has been extensively studied in the literature (Cao et al., 2003; Chappell and Scheckel, 2007; Chen et al., 2006; Cotter- 
Howells and Caporn, 1996; Hashimoto et al., 2009; Hettiarachchi and Pierzynski., 2004; Hettiarachchi et al., 2000; Hettiarachchi et al., 2001; Lin et al., 2005; Ma et al., 1993, 1995; McGowen et al., 2001; Ruby et al., 1994; Scheckel and Ryan, 2002; Scheckel and Ryan, 2004; Yang et al., 2001; Yoon et al., 2007). The possibilities of inadequate immobilization, or dissolution of pyromorphite after $\mathrm{P}$ treatment, have also been investigated (Butkus and Johnson, 2011; Debela et al., 2010).

Research has continued to explore the effect of different $\mathrm{P}$ sources on metal phosphate formation. These sources include phosphate rock (PR), diammonium phosphate (DAP), triple superphosphate (TSP), and phosphoric acid (PA) (Cao et al., 2003; Chappell and Scheckel, 2007; Hettiarachchi et al., 2000; Hettiarachchi et al., 2001; McGowen et al., 2001; Yang et al., 2001). All P sources have resulted in the reduction of $\mathrm{Pb}$ bioavailability to a variety of organisms. This decline is hypothesized to be the result of metal phosphate formation. However, treatment effects could vary across soils due to the chemical heterogeneity of soil environments. Additionally, it is not well understood how the metal phosphate species formed might be influenced by $\mathrm{P}$ source or by distance in the soil from P-containing materials, which has implications for the amount of $\mathrm{P}$ that needs to be added and the degree of mixing that is required. For example, fluid $\mathrm{P}$ delivery systems should be more effective at producing metal phosphates due to the greater solubility of $\mathrm{P}$ for reaction and a larger reaction zone due to greater diffusion. However, research in this area is lacking and is needed to better understand the influence of $\mathrm{P}$ sources in the $\mathrm{Pb}$ sequestration process.

Understanding the rate and effectiveness of $\mathrm{P}$ treatments on the sequestration of $\mathrm{Pb}$ as $\mathrm{Pb}$ phosphates, more specifically pyromorphites, methodologies that is capable of examining 
true speciation of soil $\mathrm{Pb}$ in situ must be employed. So one goal of Pb stabilization research is to measure the amount of soil $\mathrm{Pb}$ that is converted to less soluble phosphate phases, but this is problematic in heterogeneous, non-equilibrated systems (Scheckel and Ryan, 2004). More recently, speciation of metals in complex environments has been achieved by using spatially-resolved synchrotron-based techniques, such as X-ray absorption spectroscopy (XAS), coupled with statistical analysis via linear combination fitting (LCF) or principal component analysis (PCA) (Hashimoto et al., 2009; Isaure et al., 2002, Roberts et al., 2002, Scheckel and Ryan, 2004). This experimental approach combines the in situ capabilities of synchrotron-based techniques with thorough statistical analysis that allows one to compare unknown samples to well-characterized reference compounds (Scheckel and Ryan, 2004). Concerns with this procedure do exist because of the limited number of reference mineral compounds, but it has been suggested that the combined use of different synchrotron-based techniques could enhance mineral species identification (Manceau et al., 2002a). Therefore, a combination of $\mu$-X-ray fluorescence ( $\mu$-XRF), $\mu$-XAS, and $\mu$-X-ray diffraction ( $\mu$-XRD) would allow one to locate trace-metal enriched areas $(\mu-\mathrm{XRF})$, understand the approximate chemical environment ( $\mu$-XAS), and identify the mineral form ( $\mu$-XRD). This approach was employed to accomplish the following objectives: 1) investigate how different $\mathrm{P}$ sources influence the $\mathrm{Pb}$ phosphate species formed, 2) estimate the relative abundance of the $\mathrm{Pb}$ phosphate minerals formed at a given distance from the $\mathrm{P}$ amendment, and 3) observe how $\mathrm{Pb}$ speciation changes with reaction time.

\section{Materials and Methods}


Materials. The material used in this study was collected from an abandoned $\mathrm{Pb} / \mathrm{Zn}$ smelter near Dearing, KS. The material was collected from the upper $20 \mathrm{~cm}$, sieved through a stainless steel 2-mm screen, air dried, and stored in plastic containers at room temperature. This material is a smelter slag/soil mixture that has been previously studied to evaluate the effect of different $\mathrm{P}$ treatments on reduction of bioavailability (determined by physiologically based extraction test, PBET), and solubility of $\mathrm{Pb}$ (determined by toxicity characteristics leaching procedure, TCLP) (Hettiarachchi et al., 2000; Hettiarachchi et al., 2001).

Soil $\mathrm{pH}$ was measured in a 1:1 deionized water:soil mixture with a Ross Combination $\mathrm{pH}$ electrode (Thermo Orion, Beverly, MA). Total organic $\mathrm{C}$ was measured by dry combustion on a LECO CN-2000 Elemental Analyzer (LECO Corporation, St. Joseph, MI). Samples were treated with phosphoric acid prior to analysis to remove the carbonates. Total $\mathrm{P}$ for contaminated soil and $\mathrm{P}$ amendments were determined by salicylic-sulfuric acid digestion (Bremner and Mulvaney, 1982) and extractable P by Mehlich-3 (Mehlich, 1984). Filtered digests/extracts were then analyzed colorimetrically for $\mathrm{P}$ content. Cation exchange capacity (CEC) was determined by ion displacement (Jaynes and Bigham, 1986). Nitric-acid extractable metal concentrations were determined by digesting $2 \mathrm{~g}$ of material $(\leq 2-\mathrm{mm})$ with $20 \mathrm{~mL}$ of $4 M \mathrm{HNO}_{3}$ (trace metal grade) acid at 80 to $85^{\circ} \mathrm{C}$ for $4 \mathrm{~h}$ (Sposito et al., 1982). Filtered digests were then analyzed for $\mathrm{Cd}, \mathrm{Pb}$, and $\mathrm{Zn}$ by inductively coupled plasma-optical emission spectrometry (ICP-OES). Total "free" iron oxide content was estimated using the Nacitrate bicarbonate-dithionite method (Na-CBD) (Jackson et al., 1986). Extracts were analyzed for Fe using ICP-OES. Soil was analyzed for sand, silt and clay content by the 
pipette method as described by Gee and Bauder (1986). See Table 1 for details. For bulk X-ray analyses, fractionation of sand, silt, and clay was done according to Jackson (1975). The bulk X-ray analyses were conducted with a Phillips X-ray diffractormeter (Phillips Electronic Instruments, Mahwah, NJ) with a theta compensating slit and curved crystal graphite monochromator. Measurements were taken using $\mathrm{Cu} \mathrm{K \alpha}$ radiation at a wavelength of $1.54 \AA$ and were made using a continuous scanning technique at a speed of $2^{\circ} 2 \theta$ per minute. The potential was $35 \mathrm{kV}$, and the amperage $20 \mathrm{~mA}$.

Sample Preparation for X-ray Techniques. The treatments in this study included several P sources and a control that were reacted over two different time periods (4 and 52 weeks). The $\mathrm{P}$ sources included fluid phosphoric acid (PA) and ammonium polyphosphate (APP) and the granular sources phosphate rock (PR), monammonium phosphate (MAP), and triple super phosphate (TSP). In addition, a contaminated non-P amended control was prepared for comparison. MAP, APP, and TSP were commercially available fertilizer grade $\mathrm{P}$ sources and contained 221, 133, and $199 \mathrm{~g} \mathrm{P} \mathrm{kg}^{-1}$, respectively. MAP and APP contain $\mathrm{N}$ in the ammonium form and each delivered 115 and $102 \mathrm{~g} \mathrm{~N} \mathrm{~kg}^{-1}$, respectively. The PR (powder form) was from Occidental Corp. (White Springs, FL) and had $144 \mathrm{~g} \mathrm{P} \mathrm{kg}^{-1}$, while PA was technical grade phosphoric acid containing $314 \mathrm{~g} \mathrm{P} \mathrm{kg}^{-1}$. For each treatment combination, one hundred-g (dry weight basis) of contaminated waste material ( $25 \%$ gravimetric water content) was placed in a plastic container. The $\mathrm{P}$ sources were added in a line across (40 $\mathrm{mm}$ deep) the center of the container so that $20 \mathrm{mg}$ of $\mathrm{P}$ were provided by each source. The amount of $\mathrm{P}$ added reflected an average for a typical granule of the dry fertilizer materials. The $\mathrm{P}$ additions were clearly marked with plastic toothpicks and covered by additional contaminated 
material. The containers were packed to a bulk density of $1.35 \mathrm{~g} \mathrm{~cm}^{-3}$. The plastic containers were covered with Parafilm, which would not make containers fully air-tight, and allowed to incubate in the moist condition for 4 or 52 weeks. No additional water was added during the incubation. Once incubation time was 24 hours from being complete, the covers were removed from the plastic containers, and they were placed in the greenhouse to air dry. The air-dried samples were then impregnated with Buehler EpoThin ${ }^{\circledR}$ two part (epoxy/hardener) resin (Beuhler LTD., Lake Bluff, IL, USA) and allowed to cure overnight. The hardened resin was then cut using a petrographic trim saw to expose the $\mathrm{P}$ treatments and surrounding waste material. Once exposed, the surface was polished to remove saw markings, cleaned with deionized water, dried, and cemented to polystyrene plastic (0.5-mm thick) using Hillquist Thin Section Epoxy A-B (Hillquist Inc., Denver, CO, USA). Polystyrene plastic was chosen instead of glass in an attempt to eliminate as much background noise in $\mu$-XRD measurements. Once the cement was dry, thin sections were polished to a thickness of approximately $25-\mu \mathrm{m}$.

Synchrotron-based $\mu$-XRF, -XAS, and -XRD Data Collection/Analyses. Micro-XRF maps, $\mu$-XAS, and $\mu$-XRD were collected at beamline 13-BM (GeoSoilEnviro Consortium of Advanced Radiation Sources) at the Advanced Photon Source at Argonne National Laboratory, Argonne, IL. All data were collected at ambient temperature in fluorescence mode with a Ge solid-state 13-element detector (Canberra Inc., Meriden, CT, USA) and $\mu$-XRD spectra were collected with a MAR 345 Image Plate detector (MarUSA Inc., Evanston, IL, USA).

The samples were mounted on an $x-y-\theta$ stepping-motor stage. Fluorescence data for $\mathrm{Pb}$ were collected at ambient temperature for a given area (map sizes typically range 
from 3000- by $6000-\mu \mathrm{m}$ ) for all fluid and granular P treatments with a step size of $50-\mu \mathrm{m}$. Using the XRF maps, further investigation of four to six points of interest (POIs) (high relative concentrations) for $\mathrm{Pb}$ were determined moving outward from the point of $\mathrm{P}$ application. Figure 1 illustrates how POIs were selected. For granular sources, the centers of the point of application for different treatments were defined by the granule. Whereas in fluid treatments, the center of the point of application was estimated by distance from a plastic marker (toothpick) installed at the time of $\mathrm{P}$ application.

For each sample, three replicates of $\mu$-XAS spectra for each defined $\mathrm{Pb}$ POI were collected across the range of -200 to $600 \mathrm{eV}$ above the $\mathrm{L}_{\mathrm{III}}$-edge of $\mathrm{Pb}(\sim 13035 \mathrm{eV})$ in fluorescence mode and spot size was about 25-30 $\mu \mathrm{m}$. The $\mu$-XAS spectra were also collected for several known standard $\mathrm{Pb}$ compounds in transmission mode (Figure 2A). Standard $\mathrm{Pb}$ compounds include galena $[\mathrm{PbS}]$, anglesite $\left[\mathrm{PbSO}_{4}\right]$, cerussite $\left[\mathrm{PbCO}_{3}\right]$, hydrocerussite $\left[\mathrm{Pb}_{3}\left(\mathrm{CO}_{3}\right)_{2}(\mathrm{OH})_{2}\right]$, leadhillite $\left[\mathrm{Pb}_{4}\left(\mathrm{SO}_{4}\right)\left(\mathrm{CO}_{3}\right)_{2}(\mathrm{OH})_{2}\right]$, magnetoplumbite $\left[\mathrm{PbFe}_{6} \mathrm{Mn}_{6} \mathrm{O}_{19}\right], \quad$ plumboferrite $\quad\left[\mathrm{Pb}_{2} \mathrm{Mn}_{0.2} \mathrm{Mg}_{0.1} \mathrm{Fe}_{10.6} \mathrm{O}_{18.4}\right], \quad$ plumbojarosite $\left[\mathrm{PbFe}_{6}\left(\mathrm{SO}_{4}\right)_{4}(\mathrm{OH})_{12}\right], \quad$ plumbogummite $\quad\left[\mathrm{PbAl}_{3}\left(\mathrm{PO}_{4}\right)_{2}(\mathrm{OH})_{5} \quad \mathrm{H}_{2} \mathrm{O}\right], \quad$ vaquelinite $\left[\mathrm{Pb}_{2} \mathrm{Cu}\left(\mathrm{CrO}_{4}\right)\left(\mathrm{PO}_{4}\right)(\mathrm{OH})\right]$, hinsdalite $\left[\mathrm{PbAl}_{3}\left(\mathrm{PO}_{4}\right)\left(\mathrm{SO}_{4}\right)(\mathrm{OH})_{6}\right]$, and pyromorphite $\left[\mathrm{Pb}_{5}\left(\mathrm{PO}_{4}\right)_{3} \mathrm{Cl}\right]$. In addition, the $\mu$-XAS spectra were also collected for $\mathrm{Pb}$ sorbed to ferrihydrite at $\mathrm{pH}$ of 6.

The collected $\mathrm{Pb} \mu$-XAS spectra for $\mathrm{P}$ treatments and reference compounds were processed using the IFEFFIT software package (Ravel and Newville, 2005). Due to the poor quality of the extended $\mathrm{x}$-ray absorption fine structure region only $\mu$-XANES spectra could be used for $\mathrm{Pb}$ data analysis. A minimal smoothing was done using IFEFFIT software by applying a simple three-point smoothing algorithm while 
comparing carefully with the unsmoothed spectra. Processed experimental spectra were analyzed in a two-step process using Labview software for principal components analysis (PCA) and the IFEFFIT software package for linear combination fitting (LCF) (Ravel and Newville, 2005). Principal components analysis was used prior to LCF only to test the consistency of the fitting procedure and, therefore, results from PCA will not be presented. The number of significant components determined by PCA was four based either on the minimum indicator (IND) value of each component or on the weight of each component, which is directly related to how much of the signal it represents. Based on PCA analysis, maximum number of components was limited to four during the LCF. The region of 12985 to $13135 \mathrm{eV}$ for $\mathrm{Pb}$ was isolated for $\mathrm{Pb} \mathrm{LCF}$. The linear combination procedure was performed to reconstruct the contaminated soil-P amendment spectra using all of the combinations of the all reference spectra.

For the LCF procedure, the combination with the lowest reduced $\chi^{2}$ was chosen as the most likely set of components. The accuracy of LCF depends on the data quality and how well the reference spectra fit the experimental samples (Roberts et al., 2002). A reduced $\chi^{2}$ value near 1 indicates a reliable fit. Because there are a limited number of reference spectra and problems obtaining ideal standards to use in the fits, the best-fit compositions may not give the true composition, but the results can be used to describe and compare the differences between treatments. To help remedy this problem, synchrotron-based $\mu$-XRD can be teamed with $\mu$-XAS to enhance mineral species identification (Manceau et al., 2002a; 2002b). X-ray diffraction is a more definitive technique than XAS, but minerals have to be crystalline in order to utilize XRD. Therefore, a $\mu$-XRD $(\sim 17,500 \mathrm{eV})$ pattern was taken at each Pb POI to assist in species 
identification. For $\mu$-XRD spectra, the data were processed using the Fit2D software package for integrating 2D Debye-Scherer rings to one-dimensional $2 \theta$ scans (Hammersley et al., 1996). The compound cerium dioxide $\left(\mathrm{CeO}_{2}\right)$ was used as the calibrant. Cerium was chosen because it is a relatively heavy element, so it will diffract higher energy X-rays very strongly. D-spacings were calculated using Fit2D software and matched to the d-spacings of known mineral species using the powder diffraction file search manual (JCPDS-International Centre for Diffraction Data, 1987).

To elucidate information on the movement and distribution of $\mathrm{P}$ upon the addition of $\mathrm{P}$ amendments, $\mu$-XRF maps were collected at beamline 2-ID-D at the Advanced Photon Source, Argonne, IL. Thin sections, previously used at 13-BM, were peeled from the plastic slides and mounted onto a sample holder, which provided a sample thickness of approximately $25-\mu \mathrm{m}$. The sample holder was then placed on an $x-y-\theta$ stepping-motor stage. Fluorescence data for the P K-edge $(2145.5 \mathrm{eV})$ were collected at ambient temperature for a 300 - by $2000-\mu \mathrm{m}$ area for all fluid and granular P treatments. A beam size of 500- by 500-nm with a step size of $5-\mu \mathrm{m}$ was used and data were collected with a silicon drift detector. In addition, XRF spectra for two thin-film NIST multi-element standard reference materials (SRM 1832 and SRM 1833 for X-ray fluorescence spectrometry) were collected for conversion of XRF signals to relative elemental concentrations, which allows for the quantification of elements. MAPS software version 1.6.0.4 was used to quantify the distribution of $\mathrm{P}$ for each XRF map. Data was used to produce a plot of concentrations as a function of distance from the $\mathrm{P}$ amendment.

The effects of $\mathrm{P}$ amendments on $\mathrm{Zn}$ in this mine waste material and from this same incubation study has been reported separately (Baker et al., 2012). However, no 
relationship exists between the POI's used here and those used for the Zn work. Areas enriched in $\mathrm{Zn}$ were not generally also enriched in $\mathrm{Pb}$.

\section{Results and Discussion}

Bulk Mineralogical Analyses. Bulk XRD techniques can only detect crystalline materials present in concentrations $\geq 10$ to $20 \mathrm{~g} \mathrm{~kg}^{-1}$ (Ma et al., 1994), and direct identification of solid forms of many elements was not always possible by XRD. The mineralogy of the silt- $(0.05 \mathrm{~mm}$ to 0.002$)$ and clay-sized $(<0.002 \mathrm{~mm})$ fractions indicated the presence of quartz, willemite, and galena, but peak intensities for these minerals were weak, suggesting that the minerals were present at concentrations near the detection limit and/or poorly crystalline. The clay-sized fraction was enriched in $\mathrm{Fe}$, implying the presences of $\mathrm{Fe}$ oxyhydroxide solid phases, which could influence the movement of $\mathrm{P}$ and the formation of $\mathrm{Pb}$ phosphates since such solids have a high affinity for phosphates (Table 1, Pierzynski and Sims, 2005). Unfortunately, comparable data was not collected for $\mathrm{Al}$. There was no evidence for the existence of $\mathrm{Pb}$ phosphate minerals in either mineral fraction analyzed.

Synchrotron-based Pb speciation in non-amended soil. Bulk-XANES analysis of nonamended soil collected in the transmission mode indicated that the major $\mathrm{Pb}$ species were galena, cerussite and plumboferrite(Figure 2B, Table 4). Linear combination fitting showed relative abundances of $70 \%$ for galena, $20 \%$ for cerussite, and $10 \%$ for plumboferrite. According to $\mu$-XANES the major $\mathrm{Pb}$ species present in non-amended soils include cerussite, galena, and sorbed $\mathrm{Pb}$ with smaller amounts of anglesite, magnetoplumbite, and plumboferrite (Table 2). Although $\mu$-focused XANES alone 
would not be sufficient to assess the "average" molecular environment surrounding the element of interest it allows identification of minor species because we probe limited soil volume at a given time and that might be the reasoning for observing more $\mathrm{Pb}$ species with $\mu$-XANES. Because there were a limited energy range used for LCF procedure and a limited number of standard spectra, there was some uncertainty associated with the LCF procedure, $\mu$-XRD analysis was used to further aid in species identification. Micro-XRD analysis of these samples confirmed the presence of cerussite (d-spacings of 3.59, 3.50, $2.49,1.86$, and 1.93) and galena (d-spacings of 2.97, 3.43, 2.10, and 1.79) for the control samples. No other $\mathrm{Pb}$ minerals were identified by $\mu-\mathrm{XRD}$ in the control samples. Other studies, using either bulk or molecular techniques, have established that galena, anglesite, cerussite, pyromorphite, and sorbed $\mathrm{Pb}$ species are the dominant forms of $\mathrm{Pb}$ present in non-amended contaminated soils/mine tailings (Cao et al., 2002; Ostergren et al., 1999; Scheckel and Ryan, 2004; Hettiarachchi et al., 2001), which generally agrees with our data.

\section{Synchrotron-based speciation changes of $\mathrm{Pb}$ upon $\mathbf{P}$ amendment addition. The LCF} analysis of the $\mathrm{Pb} \mu$-XANES spectra for different $\mathrm{P}$ amendments indicated the presence of $\mathrm{Pb}$ phosphate minerals for all treatments in the contaminated soil (Table 2, Figure $2 \mathrm{~B}$ ). This implied that all $\mathrm{P}$ amendments were successful at converting $\mathrm{Pb}$ from more soluble species to the less soluble $\mathrm{Pb}$ phosphate minerals, namely plumbogummite and pyromorphite. However, results vary by $\mathrm{P}$ amendment, incubation time, and distance from the point of $\mathrm{P}$ application.

For PR incubated for 4 weeks, plumbogummite (55\%) was the major $\mathrm{Pb}$ species adjacent to the granule. However, $\mathrm{Pb}$ phosphate minerals became an insignificant part of 
the fit as the distance from the PR granule increased, which was anticipated due to the low solubility of PR (Lindsay, 1979). After 52 weeks, the same trend still existed. There were significant amounts of $\mathrm{Pb}$ phosphates present adjacent to the granule, $26 \%$ plumbogummite and 19\% pyromorphite, but as distance increased from 900 to $1200 \mu \mathrm{m}$ the amount of plumbogummite decreased from $50 \%$ to $5 \%$, respectively, which can again be attributed to the low solubility of PR.

To better illustrate the differences in $\mathrm{P}$ solubility, Figure 3 compares the average concentration of $\mathrm{P}$ with distance from the edge of a PR or TSP granule, and to PA droplet, relative to background soil $\mathrm{P}$ concentrations at 52 weeks. Phosphorus concentrations in the PR treatment reached background levels at approximately $1250 \mu \mathrm{m}$, which was the point where plumbogummite was estimated to be $4.9 \%$ of the $\mathrm{Pb}$ species present. In contrast, $\mathrm{P}$ concentrations for the fluid PA amendment were evenly dispersed and at appreciably higher concentrations than background levels up to $2000 \mu \mathrm{m}$. Distribution of $\mathrm{P}$ in granular MAP (data not shown) and TSP (Figure 3) were intermediate to PR and PA, while P concentration distribution in APP, another fluid P source, (data not shown) was similar to PA. These results support other studies that indicated reduced lability of granular $\mathrm{P}$ compared to liquid fertilizer formulations (Hettiarachchi et al., 2006; Lombi et al., 2005). This may influence the effectiveness of the $\mathrm{P}$ amendment at immobilizing $\mathrm{Pb}$. In particular, greater available $\mathrm{P}$ concentrations created by both fluid and highly soluble granular P sources could enhance the probability of $\mathrm{Pb}$ phosphate formation. However, more soluble $\mathrm{P}$ sources could increase eutrophication risk if $\mathrm{P}$ amended soil or mine waste were moved off site into surface waters. 
Linear combination fitting for the PA amendment incubated for 4 weeks showed a relatively even distribution of $\mathrm{Pb}$ phosphates with distance from the point of $\mathrm{P}$ application (Table 2). However, the identity of the $\mathrm{P}$ solid phases did vary. At the 52 week sampling, pyromorphite (38.5\%) became the dominant $\mathrm{Pb}$ mineral adjacent to the droplet, while the amount of plumbogummite increased at 1500 and $3300 \mu \mathrm{m}$ when compared to similar distances at the 4 week period. Additionally, it appeared as if the P gradient was nonexistent at 52 weeks in the PA treatment, which was supported by the $\mu$-XRF generated radial P distribution plot (Figure 3). As a result, the same amount of P applied through fluid PA versus that applied in granular PR influenced the $\mathrm{Pb}$ chemistry of a much larger area. However, there is concern that PA will lower soil pH (Cao et al., 2003), which could subsequently alter the bioavailability of $\mathrm{Pb}$ and other potentially toxic metals (Yoon et al., 2007).

Fluid APP could be used to supply P for reaction with less acidity, but it has not been studied. After a 4 week incubation period, $\mathrm{Pb}$ phosphate minerals dominated the $\mathrm{Pb}$ speciation at 300 and $2400 \mu \mathrm{m}$ from the point of APP application (Table 2). Additionally, this was the only amendment, either granular or fluid, besides TSP that induced pyromorphite formation within weeks of application. At $3600 \mu \mathrm{m}$, the amount of $\mathrm{Pb}$ phosphates was significantly reduced as compared to 300 and $2400 \mu \mathrm{m}$, which suggested that $\mathrm{P}$ had not yet diffused to this point or $\mathrm{P}$ availability was limited by another variable. At 52 weeks, pyromorphite was the principal $\mathrm{Pb}$ mineral adjacent to the droplet, while at 1700 and $4200 \mu \mathrm{m}$ the amount of $\mathrm{Pb}$ phosphates decreased. In contrast, the radial distribution plot for APP at 52 weeks showed an even distribution pattern similar to PA (Figure 3), suggesting that $\mathrm{Pb}$ phosphate formation was limited by other 
factors such as $\mathrm{P}$ sorption to $\mathrm{Fe}$ oxides (Sims and Pierzynski, 2005), lack of $\mathrm{Pb}$ for reaction, or competition of other metals for P (Lindsay, 1979; Nriagu, 1984).

Triple super phosphate, which is mostly monocalcium phosphate $\left[\mathrm{Ca}\left(\mathrm{H}_{2} \mathrm{PO}_{4}\right)_{2} * \mathrm{H}_{2} \mathrm{O}\right]$, was the only granular $\mathrm{P}$ source to induce pyromorphite formation at the 4 week incubation period (Table 2). This could be attributed to the small amount of acidity produced during granule dissolution that could potentially release $\mathrm{Pb}$ for reaction. In addition, the amount of $\mathrm{Pb}$ phosphate minerals produced by TSP during this time period was rather homogenous over distance, similar to the fluid P sources. At 52 weeks, the amount of pyromorphite present increased with a subsequent decrease in plumbogummite when compared to the 4 week incubation. However, the amount of $\mathrm{Pb}$ phosphate minerals formed over the entire area did not increase dramatically with time, which suggested a rather rapid initial reaction with TSP followed by a slow transformation of existing $\mathrm{Pb}$-phosphates. Results for granular MAP indicated the presence of $\mathrm{Pb}$ phosphates at all distances and incubation times. At the 4 week incubation period, the amount of $\mathrm{Pb}$ phosphates was lowest adjacent to the granule and highest at $2300 \mu \mathrm{m}$. One possible explanation for this was that another phase was controlling the availability of $\mathrm{Pb}$ or $\mathrm{P}$ in the vicinity of the granule, thus limiting $\mathrm{Pb}$ phosphate formation. At 52 weeks, there was an increase in $\mathrm{Pb}$ phosphate minerals present, but the increase occurred at $1600 \mu \mathrm{m}$ from the granule where pyromorphite was present suggesting that some other phase was limiting $\mathrm{P}$ or $\mathrm{Pb}$ availability for reaction.

Hettiarachchi et al. (2001) used the same soil contaminated by a $\mathrm{Pb} / \mathrm{Zn}$ smelter slag and found that PA and a high application of TSP were more effective at reducing bioavailable $\mathrm{Pb}$ as measured by the physiologically-based extraction procedure (PBET) 
than PR. However, in the other four contaminated materials studied, PR was equally effective as compared to both PA and TSP. This study confirmed the findings of Hettiarachchi et al. (2001) in that PA and TSP were more effective than PR at reducing $\mathrm{Pb}$ bioavailability through the formation of insoluble $\mathrm{Pb}$ phosphate minerals in the smelter slag contaminated soil. We propose that the smelter slag soil contains more discrete $\mathrm{Pb}$ minerals that are dissolved by the acidity created by both PA and TSP, thus allowing more $\mathrm{Pb}$ to react with $\mathrm{P}$ resulting in more $\mathrm{Pb}$ phosphate minerals. Phosphate rock does not produce this acidity; therefore, less $\mathrm{Pb}$ phosphates are formed.

It has been suggested that pyromorphite formation is kinetically rapid and aging increases crystallinity in a pure system (Scheckel and Ryan, 2002). However, this study indicated that pyromorphite formation in natural soil environments may actually be rather slow. Hashimoto et al. (2009) also found increased amounts of chloropyromorphite when comparing a $\mathrm{P}$ amended, $\mathrm{Pb}$ contaminated soil incubated for $380 \mathrm{~d}$ compared to $7 \mathrm{~d}$. In contaminated soils, there are a number of potential constraints that could delay pyromorphite formation such as $\mathrm{P}$ availability, $\mathrm{pH}$, presence of competing cations, accessibility of $\mathrm{Pb}$ for reaction, soil organic matter, organic acids, and soil water content, that could lead to the formation of intermediate $\mathrm{Pb}$ phosphate phases.

The formation of the $\mathrm{Pb}$ phosphate mineral plumbogummite has not been documented in any study using $\mathrm{P}$ amendments to stabilize $\mathrm{Pb}$ contaminated soils or wastes. However, studies have not attempted to speciate and quantify $\mathrm{Pb}$ phosphate formation around individual P granules or droplets. According to Nriagu (1984), the precipitation of plumbogummite during soil formation processes cannot be ignored since the mineral is expected to be more stable than pyromorphite at near neutral $\mathrm{pH}$, provided 
that both $\mathrm{Pb}$ and phosphate activities are low and $\mathrm{Al}$ is available for reaction. Pyromorphite is favored by acidic environments and high $\mathrm{P} / \mathrm{Pb}$ availabilities. In previous studies, researchers saturated the soil solution with respect to phosphate to induce pyromorphite formation and the systems were homogenized by mixing (Chappell and Scheckel, 2007; Cotter-Howells and Caporn, 1996; Hettiarachchi et al., 2001; Ma et al., 1993, 1995; Scheckel and Ryan, 2002; Scheckel and Ryan, 2004; Yang et al., 2001), which would favor pyromorphite. It was acknowledged that under normal environmental conditions it is inevitable that $\mathrm{Pb}$ or $\mathrm{P}$ availability could be a rate limiting component for pyromorphite formation (Scheckel and Ryan, 2002), which could lead to the formation of other $\mathrm{Pb}$ phosphate minerals. This study was aimed to investigate the $\mathrm{Pb}$ speciation changes in the vicinity of an individual P source at the molecular level, which ultimately led to the identification of both plumbogummite and pyromorphite.

For most $\mathrm{P}$ sources, the amount of plumbogummite decreased with time with a subsequent increase in pyromorphite (Table 2). This suggests that plumbogummite may be a metastable $\mathrm{Pb}$ phosphate mineral that transforms into pyromorphite as $\mathrm{P}$ concentrations increase. Plumbogummite is not stable in acid soil environments with elevated $\mathrm{Pb}$ and $\mathrm{P}$ concentrations (Nriagu, 1984). Therefore, with increasing distance from the point of $\mathrm{P}$ application, plumbogummite remains the only $\mathrm{Pb}$ phosphate mineral present and this is likely due to low $\mathrm{P}$ availability.

Micro-XRD Analysis. Galena was the major mineral species detected by $\mu$-XRD analysis (Table 3). This also was the major mineral species identified using XAS (Table 2). Other minerals that were identified by $\mu$-XRD include cerussite, plumboferrite, magnetoplumbite, plumbogummite, and pyromorphite. Figure 4A is an example $\mu$-XRD 
pattern for PA incubated for 52 weeks that indicates the presence of chloropyromorphite and plumboferrite $400 \mu \mathrm{m}$ from the point of application while Figure 4B is an example for PA also at 52 weeks indicating the presence of plumbogummite $1500 \mu \mathrm{m}$. Most interestingly, XRD was able to confirm many of the same trends that were discovered using XAS. For example, at the 4 week incubation, identification of plumbogummite and pyromorphite ( $\mathrm{Pb}$ phosphates) by XRD was limited primarily to the area adjacent to the point of application, which was similar to the results using XAS. However, XAS on many occasions identified $\mathrm{Pb}$ phosphates at much greater distances than XRD, but XAS can determine mineral speciation on both amorphous and crystalline materials at a much lower detection limit, while XRD was limited to only crystalline species. Crystallinity of $\mathrm{Pb}$ phosphates may be an issue at early incubation times At the 52 week incubation, $\mathrm{Pb}$ phosphate minerals can be identified by XRD at greater distances from the point of application indicating an increase in crystallinity. Pyromorphites have increased crystallinity, more distinguishable morphology, and greater stability with time after formation (Scheckel and Ryan, 2002; Stack et al., 2004), which would facilitate identification by XRD.

We have proposed that plumbogummite or plumbogummite-like minerals could be metastable $\mathrm{Pb}$ phases during the formation of pyromorphite. In addition, species could be poorly crystalline or amorphous in nature and would not strongly defract X-rays making them more difficult to detect by XRD. However, $\mu$-XRD is a quick and powerful tool when coupled with $\mu$-XAS. The use of $\mu$-XRD supported the findings of the XAS work and reduced the inherent uncertainty in the linear combination fitting procedure.

Environmental Implications. All $\mathrm{P}$ amendments were able to induce $\mathrm{Pb}$ phosphate 
formation in situ, thus potentially reducing Pb bioavailability. Pyromorphite formation is preceded by the formation of other metastable $\mathrm{Pb}$ phosphate minerals, such as plumbogummite, which was not been previously reported. This further suggests that $\mathrm{Pb}$ bioavailability may change with time. Fluid $\mathrm{P}$ amendments are superior at inducing $\mathrm{Pb}$ phosphate formation over a much greater area than granular P sources, suggesting greater $\mathrm{P}$ diffusion and subsequent availability of $\mathrm{P}$ for reaction with $\mathrm{Pb}$. The outward rate of $\mathrm{P}$ movement may have been slower in the granules due to their hygroscopic nature and the influx of water upon placement into the moist soil (Hettiarachchi et al., 2006). In general, PA was the most effective $\mathrm{P}$ amendment at producing $\mathrm{Pb}$ phosphates. This can be attributed to high levels of available $\mathrm{P}$ and the acidity of PA that can make $\mathrm{Pb}$ more readily available for reaction through the dissolution of discrete $\mathrm{Pb}$ minerals (Cao et al., 2003). Triple super phosphate was the most effective granular source at forming $\mathrm{Pb}$ phosphates. As a result, PA and TSP were the most effective $\mathrm{P}$ amendments at inducing $\mathrm{Pb}$ phosphate formation in this material, but monitoring is necessary to assure stability of $\mathrm{Pb}$ phosphates over time and to limit the impact of $\mathrm{P}$ on the environment. 


\section{References}

Adriano, D.C. 2001. Trace elements in terrestrial environments: Biogeochemistry, bioavailability, and risks of metals. $2^{\text {nd }}$ ed. Springer-Verlag, New York, NY

Agency for Toxic Substances and Disease Registry. 2005. ToxFAQS for lead [Online]. Available at www.atsdr.cdc.gov/tfacts13.html (accessed 10 Oct. 2006). ATSDR, Atlanta, GA.

Baker, L.R., G.M. Pierzynski, G.M. Hettiarachchi, K.G. Scheckel, and M. Newville. 2012. Zinc speciation in proximity to phosphate application points in a $\mathrm{Pb} / \mathrm{Zn}$ smelter contaminated soil. J. Environ. Qual. 41:1865-1873

Basta, N.T., J.A. Ryan, and R.F. Chaney. 2005. Trace element chemistry in residualtreated soil: Key concepts and metal bioavailability. J. Environ. Qual. 34:49-63.

Bremner, J.M., and C.S. Mulvaney. 1982. Salicylic acid thiosulfate modification of the Kjeldhal method to include nitrate and nitrite. p. 621. In R.H. Miller and D.R. Keeney (ed.) Methods of soil analysis. Part 2. Am. Soc. Agron., Madison, WI.

Brown, M. J. and S. Margolis. 2012. Lead in drinking water and human blood lead levels in the United States. Center for Disease Control and Prevention. MMWR Supplement. Vol. 61 [Online]. Available at http://www.cdc.gov/mmwr/pdf/other/su6104.pdf (accessed 28 Sep. 2012). CDC, Atlanta, GA.

Butkus, M. A., \& Johnson, M. C. (2011). Reevaluation of phosphate as a means of retarding lead transport from sandy firing ranges. Soil and Sediment Contamination, 20(2), 172-187. Retrieved from www.scopus.com

Cao, X., L.Q. Ma, M. Chen, S.P. Singh, and W.G. Harris. 2002. Impacts of phosphate amendments on lead biogeochemistry at a contaminated site. Environ. Sci. Technol. 36:5296-5304.

Cao, R.X., L.Q. Ma, M. Chen, S.P. Singh, and W.G. Harris. 2003. Phosphate-induced metal immobilization in a contaminated site. Environ. Pollut. 122:19-28.

Chappell, M.A., and K.G. Scheckel. 2007. Pyromorphite formation and stability after quick lime neutralization in the presence of soil and clay sorbents. Environ. Chem. 4:109-113. 
Chen, S.B., Y.G. Zhu, and Y.B. Ma. 2006. The effect of grain size of rock phosphate amendment on metal immobization in contaminated soils. J. Hazard Mater. 134:74-79.

Cotter-Howells, J., and S. Caporn. Remediation of contaminated land by formation of heavy metal phosphates. Appl. Geochem. 11:335-342.

Debela, F., Arocena, J. M., Thring, R. W., \& Whitcombe, T. (2010). Organic acidinduced release of lead from pyromorphite and its relevance to reclamation of pbcontaminated soils. Chemosphere, 80(4), 450-456. Retrieved from www.scopus.com

Gee, G.W., and J.W. Bauder. 1986. Particle size analysis. p. 399-404. In A. Klute (ed.) Methods of soil analysis. Part 1. $2^{\text {nd }}$ ed. Agron. Monogr. 9. ASA and SSSA, Madison, WI.

Hammersley, A.P., S.O. Svensson, M. Hanfland, A.N. Fitch, and D. Häusermann. 1996. Two-dimensional detector software: From real detector to idealized image or twotheta scan. High Press. Res. 14:235-248.

Hashimoto, Y., Takaoka, M., Oshita, K., \& Tanida, H. (2009). Incomplete transformations of $\mathrm{pb}$ to pyromorphite by phosphate-induced immobilization investigated by X-ray absorption fine structure (XAFS) spectroscopy. Chemosphere, 76(5), 616-622. Retrieved from www.scopus.com

Hettiarachchi, G.M., E. Lombi, M.J. McLaughlin, D. Chittleborough, and P. Self. 2006. Density changes around phosphorus granules and fluid bands in a calcareous soil. Soil Sci. Soc. Am. J. 70:960-966.

Hettiarachchi, G.M., and G.M. Pierzynski. 2004. Soil lead bioavailability and in situ remediation of lead-contaminated soils: A review. Environ. Prog. 23:78-93.

Hettiarachchi, G.M., G.M. Pierzynski, and M.D. Ransom. 2000. In situ stabilization of soil lead using phosphorus and manganese oxide. Environ. Sci. Tech. 34:46144619.

Hettiarachchi, G.M., G.M. Pierzynski, and M.D. Ransom. 2001. In situ stabilization of lead using phosphorus. J. Environ. Qual. 30:1214-1221.

Isaure, M.-P., A. Laboudigue, A. Manceau, G. Sarret, C. Tiffreau, P. Trocellier, G. Lamble, J.-L. Hazemann, and D. Chateigner. 2002. Quantitative Zn speciation in 
a contaminated dredged sediment by $\mu$-PIXE, $\mu$-SXRF, EXAFS spectroscopy and principal components analysis. Geochim. Cosmochim. Acta 66:1549-1567.

Jackson, M.L. 1975. Soil chemical analysis-advanced course. $2^{\text {nd }}$ ed. Dep. Soil Sci., Univ. of Wisconsin, Madison, WI.

Jackson, M.L., C.H. Lim, and L.W. Zelazny. 1986. Oxides, hydroxides and aluminosilicates. p. 101-150. In A. Klute (ed.) Methods of soil analysis. Part 1. $2^{\text {nd }}$ ed. Agron. Monogr. 9. ASA and SSSA, Madison, WI.

Jaynes, W.F., and J.M. Bigham. 1986. Multiple cation-exchange capacity measurements on standard clays using a commercial mechanical extractor. Clays Clay Miner. 34:93-98.

JCPDS-International Centre for Diffraction Data. 1987. Powder diffraction file inorganic phases search manual (Hanawalt method). JCPDS, Swarthmore, PA.

Lin, C.W., J. Lian, and H.H. Fang. 2005. Soil lead immobilization using phosphate rock. Water Air Soil Pollut. 161:113-123.

Lindsay, W.L. 1979. Chemical equilibria in soils. Wiley, New York, NY.

Kilgour, D.W., R.B. Moseley, M.O. Barnett, K.S. Savage, and P.M. Jardine. Potential negative consequences of adding phosphorus-based fertilizers to immobilize lead in soil. J. Environ. Qual. 37:1736-1740.

Lombi, E., M.J. McLaughlin, C. Johnston, R.D. Armstrong, and R.E. Holloway. 2005. Mobility, solubility, and lability of fluid and granular forms of $\mathrm{P}$ fertilizer in calcareous and non-calcareous soils under laboratory conditions. Plant Soil 269:25-34.

Ma, Q.Y., T.J. Logan, and S.J. Traina. 1995. Lead immobilization from aqueous solutions and contaminated soils using phosphate rocks. Environ. Sci. Technol. 29:1118-1126.

Ma, Q.Y., T.J. Logan, S.J. Traina, and J.A. Ryan. 1994. Effects of $\mathrm{NO}_{3}{ }^{-}, \mathrm{Cl}^{-}, \mathrm{F}^{-}, \mathrm{SO}_{4}{ }^{2-}$, and $\mathrm{CO}_{3}{ }^{2-}$ on $\mathrm{Pb}^{2+}$ immobilization by hydroxyapatite. Environ. Sci. Technol. 28:408-418.

Ma, Q.Y., S.J. Traina, T.J. Logan, and J.A. Ryan. 1993. In situ lead immobilization by apatite. Environ. Sci. Technol. 27:1803-1810.

Manceau, A., M.A. Marcus, and N. Tamura. 2002a. Quantitative speciation of heavy 
metals in soils and sediments by X-ray techniques. Rev. Mineral. Geochem. 49:321-428.

Manceau, A., N. Tamura, M.A. Marcus, A.A. MacDowell, R.S. Celestre, R.E. Sublett, G. Sposito, and H.A. Padmore. 2002b. Deciphering Ni sequestration in soil ferromanganese nodules by combining X-ray fluorescence, absorption, and diffraction at micrometer scales of resolution. Am. Mineral. 87:1494-1499.

Mehlich, A. 1984. Mehlich 3 soil test extractant: A modification of Mehlich-2 extractant. Commun. Soil Sci. Plant Anal. 15(12): 1409-1416.

Mench, M., V. Didier, M. Loffler, Am. Gomez, and P. Masson. 1994. A mimicked insitu remediation study of metal-contaminated soils with emphasis on $\mathrm{Cd}$ and $\mathrm{Pb}$. J. Environ. Qual. 23:58-63.

McGowen, S.L., N.T. Basta, and G.O. Brown. 2001. Use of diammonium phosphate to reduce heavy metal solubility and transport in smelter-contaminated soil. J. Environ. Qual. 30:493-500.

Nriagu, J.O. 1974. Lead orthophosphates-IV. Formation and stability in the environment. Geochim. Cosmochim. Acta 38:887-989.

Nriagu, J.O. 1984. Formation and stability of base metal phosphates in soils and sediments. p. 318-329. In J.O. Nriagu and P.B. Moore (ed.) Phosphate Minerals. Springer, London.

Ostergren, J.D., G.E. Brown Jr., G.A. Parks, and T.N. Tingle. 1999. Quantitative speciation of lead in selected mine tailings from Leadville, $\mathrm{CO}$.

Porter, S.K, K.G. Scheckel, C.A. Impellitteri, and J.A. Ryan. 2004. Toxic metals in the environment: thermodynamic considerations for possible immobilization strategies for Pb, Cd, As, and Hg. Crit. Rev. Environ. Sci. Technol. 34: 495-604.

Ravel, B., and M. Newville. 2005. ATHENA, ARTEMIS, HEPHAESTUS: Data analysis for X-ray absorption spectroscopy using IFEFFIT. J. Synchrotron Radiat. 12:537-541.

Roberts, D.R., A.C. Scheinost, D.L. Sparks. 2002. Zinc speciation in a smeltercontaminated soil profile using bulk and microspectroscopic techniques. Envron. Sci. Technol. 36:1742-1750.

Ruby, M.V., A. Davis, and A. Ncholson. 1994. In situ formation of lead phosphates in 
soils as a method to immobilize lead. Environ. Sci. Technol. 28:646-654.

Ryan, J.A., K.G Scheckel, W.R Berti, S.L Brown, S.W Casteel, R.L Chaney, J. Hallfrisch, M. Doolan, P. Grevatt, M. Maddaloni, and D. Mosby. 2004. Peer reviewed: reducing children's risk from lead in soil. Environ. Sci. Technol. 38: 18A-24A.

Scheckel, K.G., and J.A. Ryan. 2002. Effects of aging and pH on dissolution kinetics and stability of chloropyromorphite. Environ. Sci. Technol. 36:2198-2204.

Scheckel, K.G., and J.A. Ryan. 2004. Spectroscopic speciation of lead in phosphateamended soils. J. Environ. Qual. 33:1288-1295.

Scheckel, K.G., R.L. Chaney, N.T. Basta, and J.A. Ryan. 2009. Advances in assessing bioavailability of metal (loid) s in contaminated soils. Adv. Agron. 104:1-52.

Sims, J.T., and G.M. Pierzynski. 2005. Chemistry of phosphorus in soils. In M.A. Tabatabai and D.L. Sparks (ed.) Chemical processes in soils. SSSA Book Ser. 8. SSSA. Madison, WI.

Sposito, G., L.J. Lund, and A.C. Chang. 1982. Trace metal chemistry in arid-zone field soils amended with sewage sludge: I. Fractionation of $\mathrm{Ni}, \mathrm{Cu}, \mathrm{Zn}, \mathrm{Cd}$, and $\mathrm{Pb}$ in solid phases. Soil Sci. Soc. Am. J. 46:260-264.

Stack, A.G., R. Erni, N.D. Browning, and W.H. Casey. 2004. Pyromorphite growth on lead-sulfide surfaces. Environ. Sci. Technol. 38:5529-5534.

Yang, J., D.E. Mosby, S.W. Casteel, and R.W. Blanchar. 2001. Lead immobilization using phosphoric acid in a smelter-contaminated urban soil. Environ. Sci. Technol. 35:3553-3559.

Yoon, J.K., X.D. Cao, and L.Q. Ma. 2007. Application methods affect phosphorusinduced lead immobilization from a contaminated soil. J. Environ. Qual. 36:373378. 


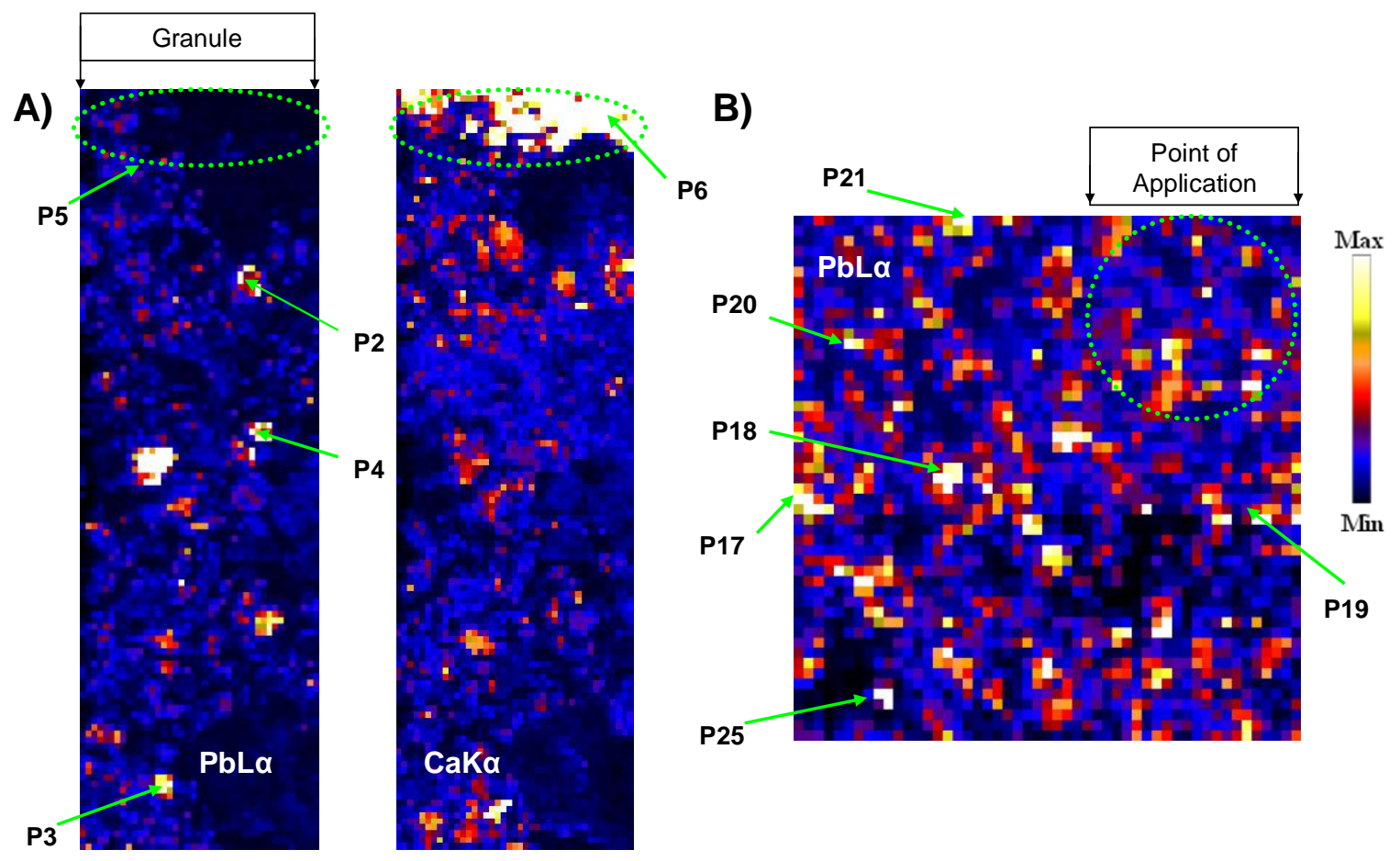

Figure 1. Micro-X-ray fluorescence maps of a) $\mathrm{Pb}$ and $\mathrm{Ca}$ for soil incubated with $\mathrm{PR}$ for 1 month and b) Pb for soil incubated with PA for 1 month. Area of a single map is a) $2000-$ by $6000-\mu \mathrm{m}$ and b) 2500 - by $2500-\mu \mathrm{m}$. The color scheme used ranges from white or yellow for high fluorescence signal to blue or black for low fluorescence signal. Shading is relative across each map. The markers P1 to P6 in a) and P17 to P25 in b) represent locations for which $\mu$-X-ray absorption near-edge structure (XANES) and $\mu$-Xray diffraction (XRD) analyses were conducted. Calcium is shown in a) to illustrate the location of a PR granule. 


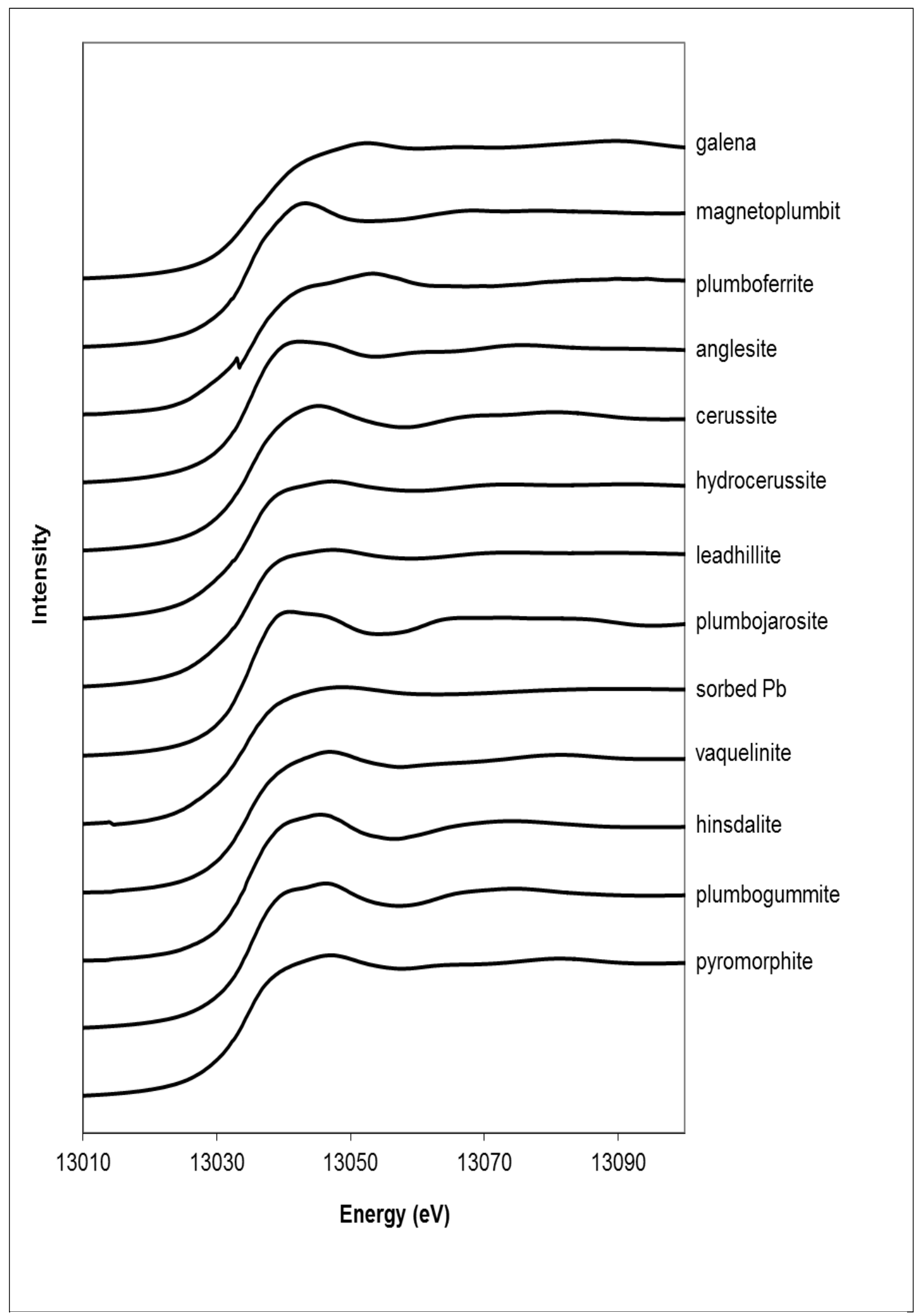

Figure 2. A) Normalized $\mathrm{Pb} \mu$-XANES spectra for all standard $\mathrm{Pb}$ compounds used for linear combination fitting 


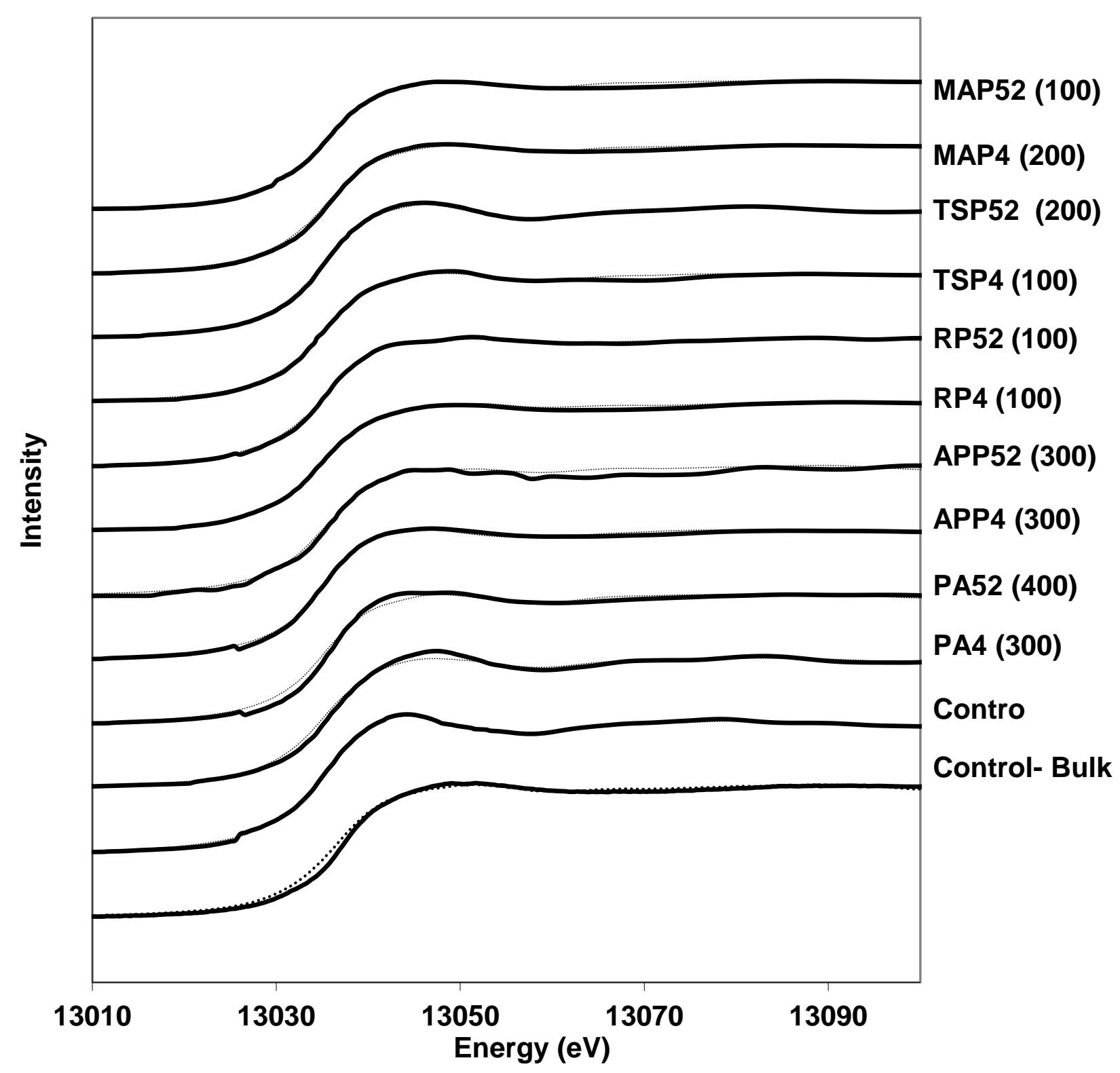

Figure 2. B) Normalized $\mathrm{Pb} \mu$-XANES spectra (solid lines) for the $\mathrm{Pb}$ L-edge $\mathrm{X}$-ray absorption spectroscopic data. Data were collected from points 100- to $400-\mu \mathrm{m}$ from the edge of a granule or the center of a droplet, except the control which is a representative spectra from the incubated treatment with no $\mathrm{P}$ amendment, and the spectra for bulk samples of the control. Dotted lines indicate the best linear combination fits using all the standard $\mathrm{Pb}$ mineral compounds. Control-bulk: bulk-XANES-unamended control, Control: representative $\mu$-XANES spectra-unamended sample, PR: phosphate rock, TSP: triple super phosphate, PA: phosphoric acid, APP: ammonium polyphosphate. The numbers 4 and 52 indicate the incubation period in weeks. 


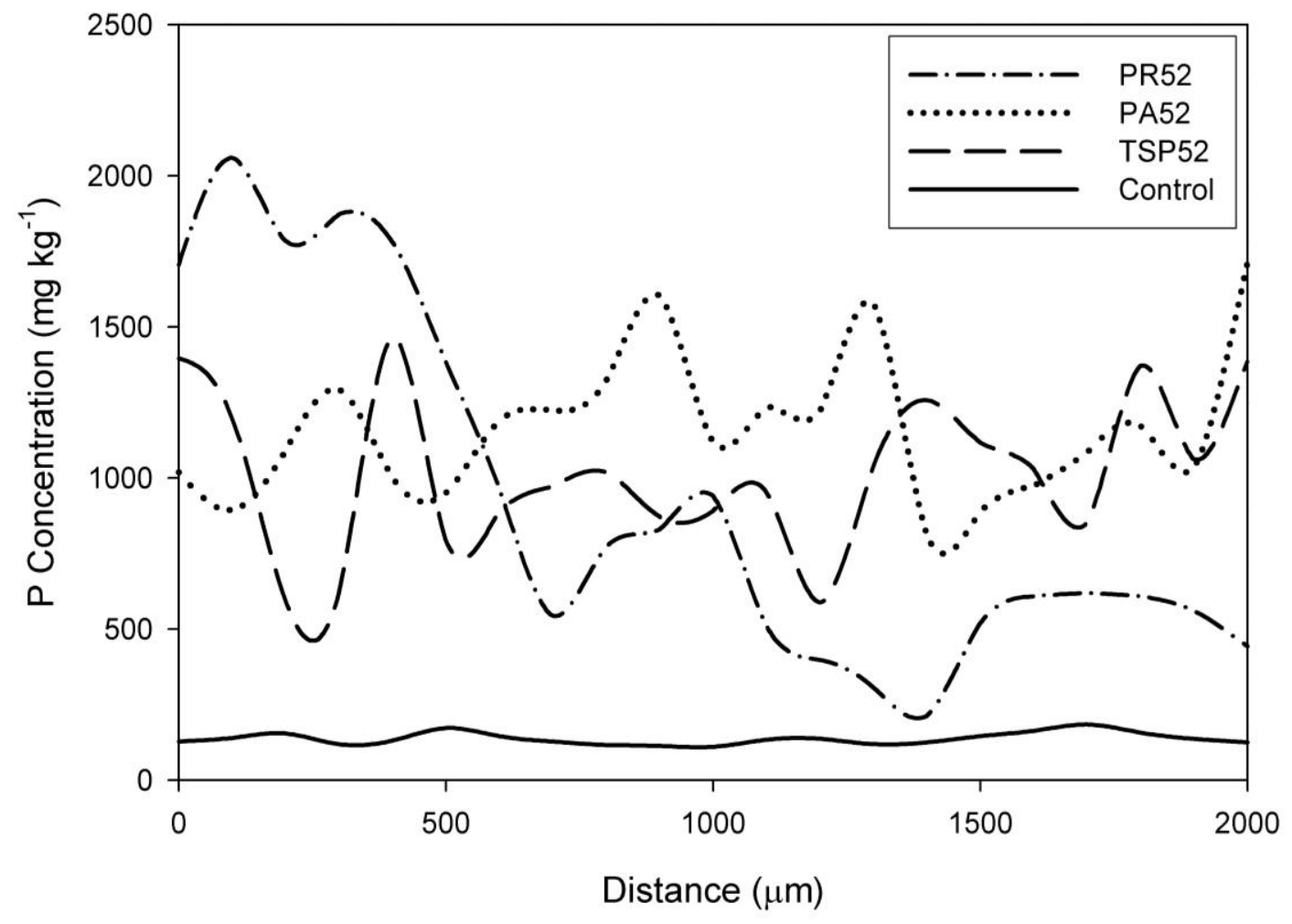

Figure 3. A radial distribution plot at 52 weeks for $P$ generated by using $\mu$-XRF maps for soils treated with PR, PA, and TSP. Point of application is at $0 \mu \mathrm{m}$. The solid line represents the background $\mathrm{P}$ concentration measured across the control soil. PR52: phosphate rock at 52 weeks, PA52: phosphoric acid at 52 weeks, TSP52: triple super phosphate at 52 weeks, and control: amended sample. 
Figure 4A

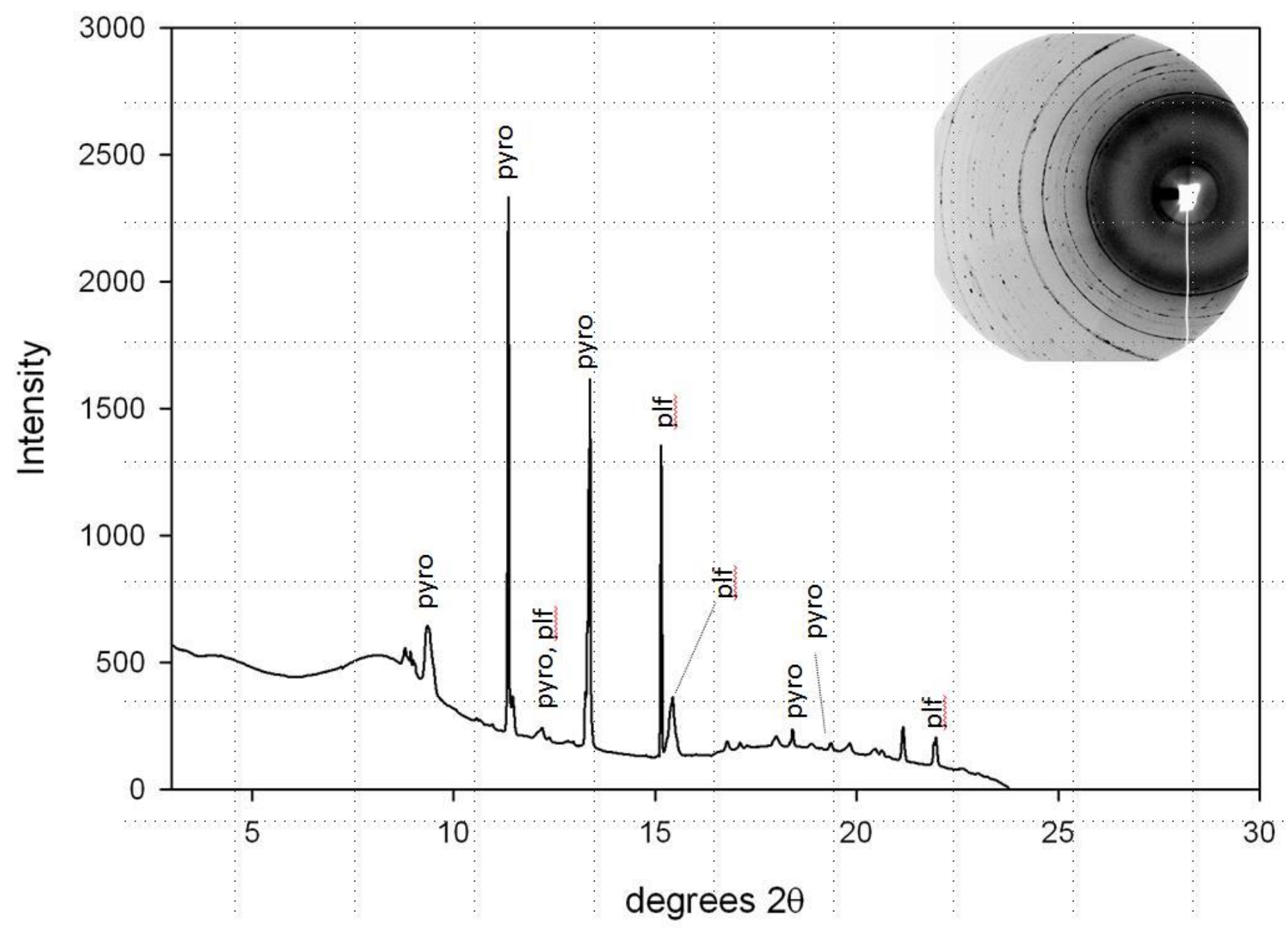

Figure 4. A) Micro-XRD pattern for treatment PA52 at $400 \mu \mathrm{m}$ from the center of treatment. Original Debye-Sherer rings are located in the top-right hand corner of the graph. Species detected are pyro (chloropyromorphite $\left[\mathrm{Pb}_{5}\left(\mathrm{PO}_{4}\right)_{3}(\mathrm{Cl})\right]$ with d-spacings of $2.97,2.89,4.13,3.27,2.06$, and 1.92) and plf (plumboferrite $\left[\mathrm{Pb}_{2} \mathrm{Mn}_{0.2} \mathrm{Mg}_{0.1} \mathrm{Fe}_{10.6} \mathrm{O}_{18.4}\right]$ with dspacings of 2.64, 2.97, 2.44, and 1.68). 
Figure 4B

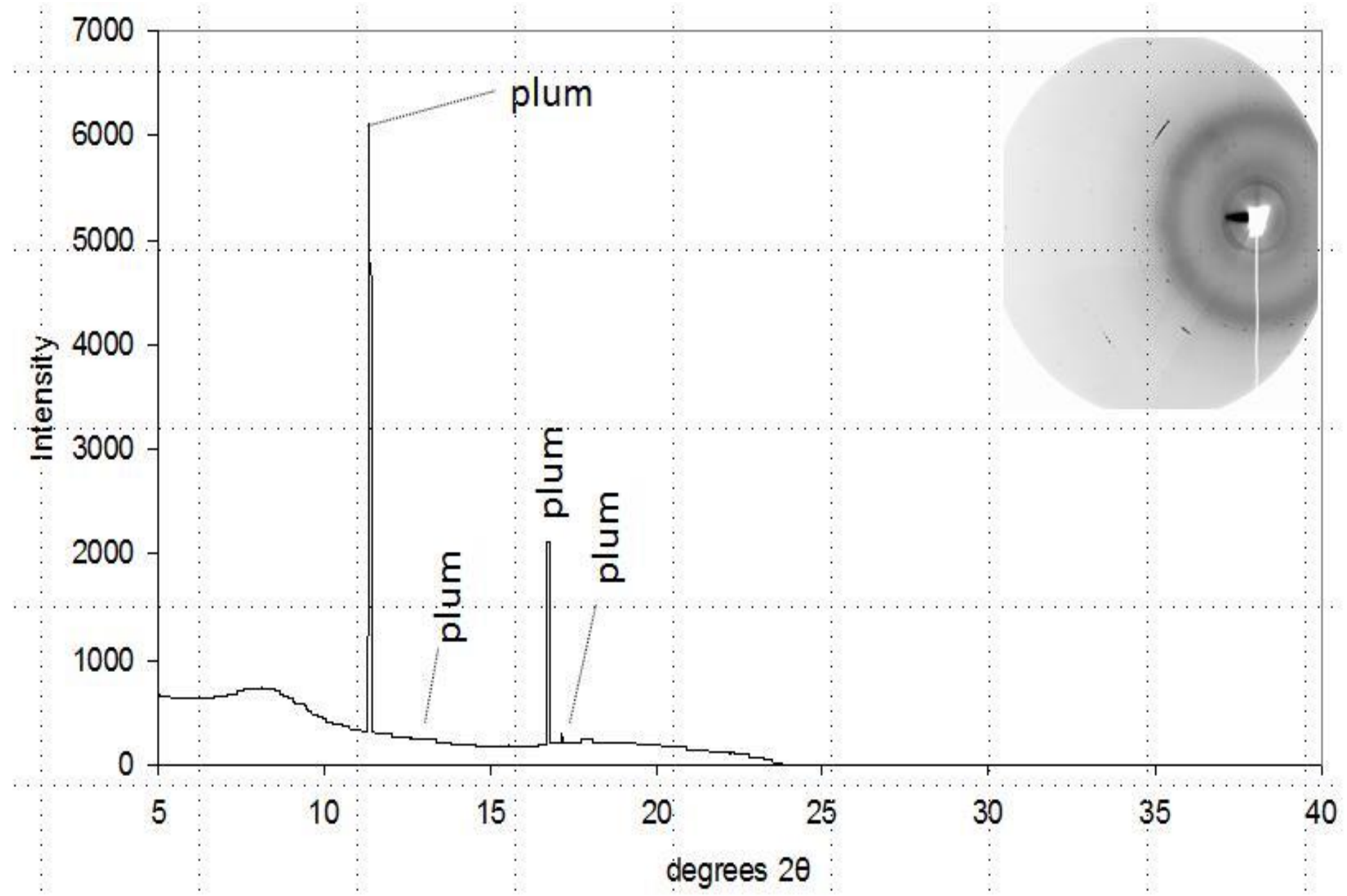

Figure 4. B) Micro-XRD pattern for PA52 at $1500 \mu \mathrm{m}$ from the center of the treatment. All peaks are assigned to plumbogummite with d-spacings of 2.97, 5.70, 3.50, 2.22, 2.21, 1.90, 3.44, and 5.57. 
Table 1. Selected soil properties.

\begin{tabular}{|c|c|}
\hline Property & Value \\
\hline $\mathrm{pH}$ & 6.4 \\
\hline Total organic $\mathrm{C}, \mathrm{g} \mathrm{kg}^{-1}$ & 39.7 \\
\hline Total $\mathrm{P}, \mathrm{mg} \mathrm{kg}^{-1}$ & 152 \\
\hline Mehlich-3 extractable $\mathrm{P}, \mathrm{mg} \mathrm{kg}^{-1}$ & 18.0 \\
\hline $\mathrm{Na}-\mathrm{CBD} \mathrm{Fe} \mathrm{mg} \mathrm{kg}^{-1}$ & 38000 \\
\hline Total $\mathrm{Pb}, \mathrm{mg} \mathrm{kg}^{-1}$ & 24300 \\
\hline Total Zn, mg kg${ }^{-1}$ & 72900 \\
\hline Total Cd, $\mathrm{mg} \mathrm{kg}^{-1}$ & 103 \\
\hline Cation exchange capacity, ${\mathrm{cmolc} \mathrm{kg}^{-1}}^{-1}$ & 42.3 \\
\hline Sand, $\mathrm{mg} \mathrm{kg}^{-1}$ & 764 \\
\hline Silt, $\mathrm{mg} \mathrm{kg}^{-1}$ & 164 \\
\hline Clay, $\mathrm{mg} \mathrm{kg}^{-1}$ & 72 \\
\hline
\end{tabular}


Table 2. Percentages of $\mathrm{Pb}$ species from selected POIs for control and $\mathrm{P}$ treated soils as determined by linear combination fitting of $\mu$-X-ray absorbtion near-edge structure ( $\mu$-XANES) spectra 4 and 52 weeks after $P$ amendment addition. Typical uncertainties in the percentages listed for each standard component are $5 \%$.

\begin{tabular}{|c|c|c|c|c|c|c|c|c|c|c|}
\hline Sample $\dagger$ & Distance $\ddagger$ & Ce\# & $\mathbf{G a}$ & $\mathbf{P g}$ & $\mathbf{P y}$ & Мp & Pf & Ag & $\mathrm{SPb}$ & $x^{2 \dagger \dagger}$ \\
\hline Control & -- & 54 & 3 & - & -- & 43 & - & -- & - & 0.18 \\
\hline Control & -- & -- & 14 & -- & -- & -- & 4 & 18 & 64 & 0.62 \\
\hline Control & -- & -- & 51 & -- & -- & -- & 9 & 40 & & 0.58 \\
\hline 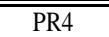 & 100 & -- & 36 & $\overline{c 55}$ & -- & 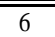 & $\overline{3}$ & ב-- & -- & 0.72 \\
\hline PR4 & 2200 & 62 & 30 & 115 & -- & -- & -- & -- & -- & 0.22 \\
\hline PR4 & 5100 & -- & 55 & 1 & -- & 16 & -- & -- & 28 & 0.28 \\
\hline PR52 & 100 & -- & 22 & 26 & 19 & -- & 33 & -- & -- & 0.19 \\
\hline PR52 & 900 & 36 & 14 & 50 & -- & -- & -- & -- & -- & 0.15 \\
\hline PR52 & 1200 & -- & 44 & 5 & -- & -- & 23 & 29 & -- & 0.23 \\
\hline TSP4 & 100 & 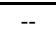 & 43 & 35 & 8 & -- & 13 & $\begin{array}{l}-- \\
\end{array}$ & - & 0.30 \\
\hline TSP4 & 1800 & -- & 59 & 31 & -- & 10 & -- & -- & -- & 0.55 \\
\hline TSP4 & 5200 & -- & 47 & 31 & -- & 17 & 6 & -- & -- & 0.17 \\
\hline TSP52 & 200 & 67 & -- & 14 & 19 & -- & -- & -- & -- & 0.66 \\
\hline TSP52 & 2000 & -- & 45 & 33 & -- & -- & -- & 22 & -- & 0.27 \\
\hline TSP52 & 3100 & 40 & 24 & 36 & -- & -- & -- & -- & -- & 0.19 \\
\hline MAP4 & 200 & -- & 48 & 17 & -- & 36 & -- & -- & -- & 0.24 \\
\hline MAP4 & 1500 & -- & -- & 8 & -- & -- & 28 & 25 & 39 & 0.86 \\
\hline MAP4 & 2300 & -- & 60 & 32 & -- & -- & 9 & -- & -- & 0.39 \\
\hline MAP52 & 100 & -- & 51 & 31 & -- & 18 & -- & -- & -- & 0.10 \\
\hline MAP52 & 1600 & 31 & -- & 43 & 15 & 11 & -- & -- & -- & 0.86 \\
\hline MAP52 & 3600 & -- & 63 & 30 & -- & -- & -- & -- & 7 & 0.28 \\
\hline PA4 & 300 & -- & 49 & 32 & -- & -- & 19 & -- & $-\overline{-}$ & 0.28 \\
\hline PA4 & 1800 & -- & 73 & 27 & -- & -- & -- & -- & -- & 0.11 \\
\hline PA4 & 2500 & 36 & 47 & 17 & -- & -- & -- & -- & -- & 0.83 \\
\hline PA52 & 400 & -- & 18 & -- & 39 & 9 & 35 & -- & -- & 0.81 \\
\hline PA52 & 1500 & -- & 43 & 57 & -- & -- & -- & -- & -- & 0.10 \\
\hline PA52 & 3300 & -- & 52 & 48 & -- & -- & -- & -- & -- & 0.13 \\
\hline APP4 & 300 & 30 & 11 & 38 & 22 & -- & -- & -- & -- & 0.50 \\
\hline APP4 & 2400 & -- & 37 & 56 & 7 & -- & -- & -- & -- & 0.37 \\
\hline APP4 & 3600 & -- & 89 & 11 & -- & -- & -- & -- & -- & 0.38 \\
\hline APP52 & 300 & -- & 21 & -- & 56 & 5 & 19 & -- & -- & 0.56 \\
\hline APP52 & 1700 & -- & 45 & 10 & -- & 37 & -- & -- & 8 & 0.17 \\
\hline APP52 & 4200 & -- & 65 & 14 & -- & 21 & -- & -- & -- & 0.11 \\
\hline
\end{tabular}

$\dagger$ Control: non-P amended; PR: Phophate rock; TSP: Triple super phosphate; MAP: Monammonium phosphate; PA: Phosphoric acid; APP: Ammonium polyphosphate. Number following treatment indicates incubation time (4 or 52 weeks).

$\$$ Distance in $\mu \mathrm{m}$ from the P treatment. For fluid sources (PA and APP) this distance begins at the approximate center of the point of application. For granular sources (PR, TSP, and MAP) this distance begins at the edge of the granule. Points of interest for the controls were taken randomly where high relative $\mathrm{Pb}$ concentrations were present.

\# Ce: Cerussite, Ga: Galena, Pg: Plumbogummite, Py: Pyromorphite, Mp: Magnetoplumbite, Pf: Plumboferrite, Ag: Anglesite, SPb: Sorbed Pb

$\dagger \uparrow$ Values closer to 0 and $\leq 1$ indicate more reliable fits. 
Table 3. A summary of $\mu$-XRD analysis for Pb POI's that corresponds to Pb POI's selected for $\mu$-XAS in Table 2.

\begin{tabular}{ccc}
\hline Sample & Distance $\ddagger$ & Minerals Detected by $\boldsymbol{\mu}$-XRD Analysis \\
\hline Control & - & Galena, Cerussite \\
Control & - & Galena, Cerussite \\
\hline PR4 & 100 & Galena, Plumbogummite \\
PR4 & 2200 & Cerussite \\
PR4 & 5100 & Galena \\
PR52 & 100 & Pyromorphite, Plumboferrite \\
PR52 & 900 & Cerussite, Plumbogummite \\
PR52 & 1200 & Galena, Plumboferrite \\
\hline TSP4 & 100 & Galena, Plumbogummite \\
TSP4 & 1800 & Galena \\
TSP4 & 5200 & Galena \\
TSP52 & 200 & Cerussite, Pyromorphite \\
TSP52 & 2000 & Galena \\
TSP52 & 3100 & Cerussite, Plumbogummite \\
\hline MAP4 & 200 & Galena, Magnetoplumbite \\
MAP4 & 1500 & Plumboferrite \\
MAP4 & 2300 & Galena \\
MAP52 & 100 & Galena \\
MAP52 & 1600 & Plumbogummite \\
MAP52 & 3600 & Galena \\
\hline PA4 & 300 & Galena \\
PA4 & 1800 & Galena \\
PA4 & 2500 & Cerussite, Galena \\
PA52 & 400 & Pyromorphite, Plumboferrite \\
PA52 & 1500 & Plumbogummite \\
PA52 & 3300 & Galena, Plumbogummite \\
\hline APP4 & 300 & Galena, Plumbogummite \\
APP4 & 2400 & Galena \\
APP4 & 3600 & Pyromorphite \\
APP52 & 100 &
\end{tabular}

$\uparrow$ Control: non-P amended; PR: Phophate rock; TSP: Triple super phosphate; MAP: Monammonium phosphate; PA: Phosphoric acid; APP: Ammonium polyphosphate. Number following treatment indicates incubation time (4 or 52 weeks).

$\$$ Distance in $\mu \mathrm{m}$ from the P treatment. For fluid sources (PA and APP) this distance begins at the approximate center of the point of application. For granular sources (PR, TSP, and MAP) this distance begins at the edge of the granule. Points of interest for the controls were taken randomly where high relative $\mathrm{Pb}$ concentrations were present. 
Table 4. A summary of $\mathrm{Pb}$ speciation results with different $\mathrm{x}$-ray techniques

\begin{tabular}{|c|c|c|c|c|}
\hline Sample & $\begin{array}{l}\text { Laboratory } \\
\text { based-XRD }\end{array}$ & Micro-XRD & $\begin{array}{l}\text { Bulk- } \\
\text { XANES }\end{array}$ & Micro- XANES \\
\hline Control & $\begin{array}{l}\text { None } \\
\text { identified }\end{array}$ & cerussite, galena & $\begin{array}{l}\text { cerussite, } \\
\text { galena, } \\
\text { plumboferrite }\end{array}$ & $\begin{array}{l}\text { cerussite, galena, sorbed } \mathrm{Pb} \text {, } \\
\text { magnetoplumbite, } \\
\text { plumboferrite, anglesite }\end{array}$ \\
\hline PR4 & - & $\begin{array}{l}\text { galena, cerussite, } \\
\text { plumbogummite }\end{array}$ & - & $\begin{array}{l}\text { cerussite, galena, } \\
\text { plumbogummite, } \\
\text { magnetoplumbite, } \\
\text { plumboferrite, sorbed } \mathrm{Pb}\end{array}$ \\
\hline PR52 & - & $\begin{array}{l}\text { pyromorphite, } \\
\text { plumboferrite, cerussite, } \\
\text { plumbogummite, galena }\end{array}$ & - & $\begin{array}{l}\text { plumbogummite, } \\
\text { plumboferrite, galena, } \\
\text { cerussite pyromorphite, } \\
\text { anglesite }\end{array}$ \\
\hline TSP4 & - & galena, plumbogummite, & - & $\begin{array}{l}\text { galena, plumbogummite, } \\
\text { plumboferrite, } \\
\text { pyromorphite, } \\
\text { magnetoplumbite }\end{array}$ \\
\hline TSP52 & - & $\begin{array}{l}\text { cerussite, pyromorphite, } \\
\text { plumbogummite, } \\
\text { galena }\end{array}$ & - & $\begin{array}{l}\text { cerussite, galena, } \\
\text { plumbogummite, } \\
\text { pyromorphite, anglesite }\end{array}$ \\
\hline MAP4 & - & $\begin{array}{l}\text { galena, } \\
\text { magnetoplumbite, } \\
\text { plumboferrite, }\end{array}$ & - & $\begin{array}{l}\text { galena, plumbogummite, } \\
\text { pyromorphite, } \\
\text { plumboferrite, anglesite, }\end{array}$ \\
\hline MAP52 & - & $\begin{array}{l}\text { plumbogummite, } \\
\text { Plumbogummite, } \\
\text { galena }\end{array}$ & - & $\begin{array}{l}\text { sorbed } \mathrm{Pb} \\
\text { galena, plumbogummite, } \\
\text { magnetoplumbite, cerussite, } \\
\text { pyromorphite }\end{array}$ \\
\hline PA4 & - & galena, cerussite & - & $\begin{array}{l}\text { galena, plumbogummite, } \\
\text { plumboferrite, cerussite }\end{array}$ \\
\hline
\end{tabular}




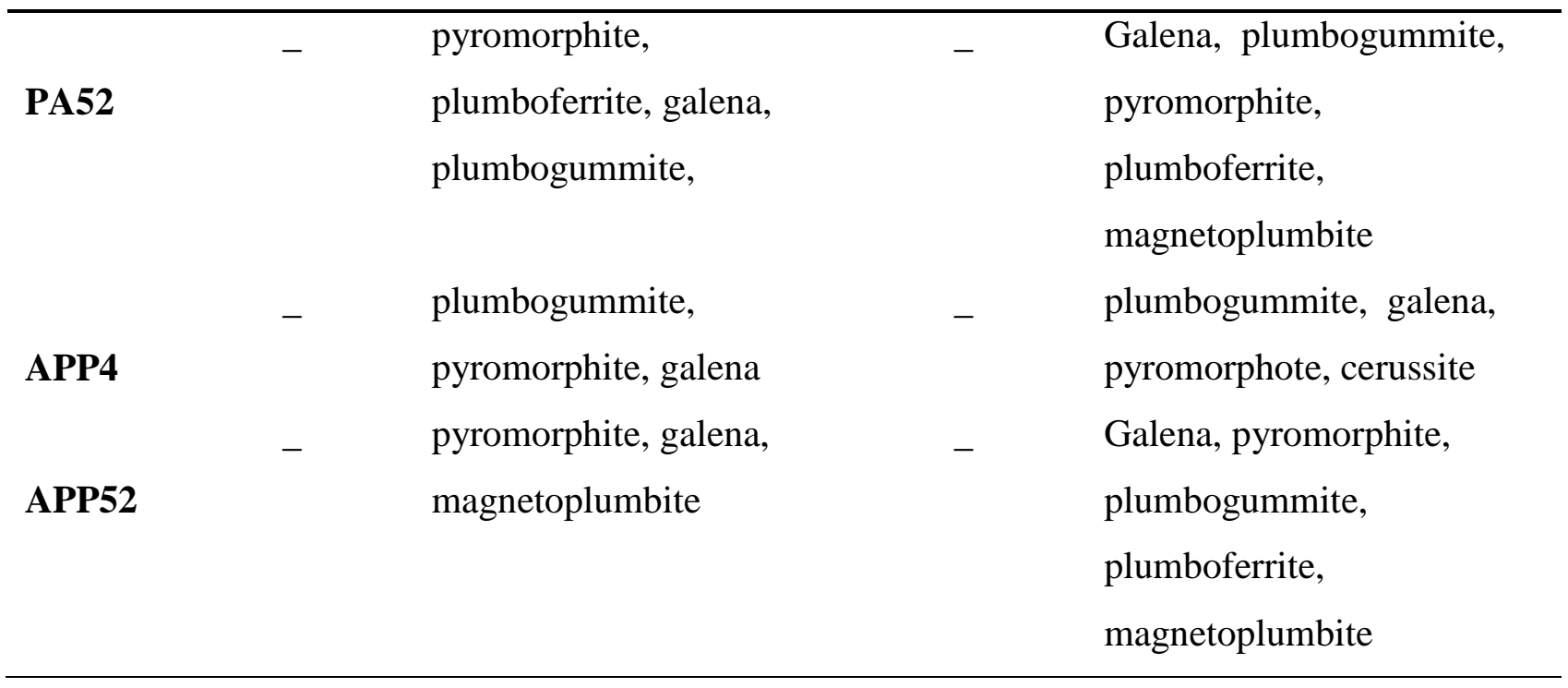

